\title{
Influence of nitrogen on guttation fluid and development of bacterial blight of rice
}

\author{
R. Kiran*, M. S. Hunjan and P. P. Singh \\ Department of Plant pathology, Punjab Agricultural University, Ludhiana-141004 (Punjab), INDIA \\ *Corresponding author. E-mail: paurajkiran@gmail.com
}

Received: May 31, 2015; Revised received: June 02, 2016; Accepted: August 11, 2016

\begin{abstract}
Bacterial blight disease of rice is major constraint in rice cultivation. This disease is influenced by prevailing weather conditions, rice physiology and nutrition. The experiment was carried out to assess the role of nitrogenous fertilizer on development of bacterial blight disease of rice and Xanthomonas oryzae pv. oryzae density in guttation fluid. Disease development increased with increase in nitrogen fertilizer, among four doses of nitrogen tested (control, 36, 54,72 kg urea/acre), disease severity was maximum in the plot supplied with highest dose of nitrogen i.e. $72 \mathrm{~kg}$ urea/acre at both seedling (19.3\%) and tillering stage (32.4\%) at 30 days after inoculation. The highest population density of $X$. oryzae pv. oryzae $(6.02 \mathrm{log} \mathrm{cfu} / \mathrm{ml})$ was also recovered in guttation fluid collected from $X . o r y z a e p v$. oryzae inoculated plants at tillering stage, from the plots supplied with highest dose $(72 \mathrm{~kg}$ urea/acre) of nitrogen.Scanning electron microscopic studies also revealed intense colonization by $X$. oryzae pv. oryzae in rice leaves supplied with high nitrogen dose.
\end{abstract}

Keywords: Bacterial blight, Guttation, Nitrogen, Rice, Scanning electron microscope

\section{INTRODUCTION}

Bacterial blight of rice caused by Xanthomonas oryzae pv. oryzae, is the most devastating disease in southeast Asia including India causing significant yield losses, up to 50 per cent yield losses in rice crop (Gnanamanickam et al, 1999). This disease appeared in epiphytotic form in 1960, 1972, 1980 (Raina et al, 1981) and again in the years 1985, 1991 and 1992, it appeared in severe forms in many rice fields of Punjab causing losses from 6-76 per cent in grain yield (Brar, 1992). The reduction of grain yield due to this disease varies and it depends upon the stage of the crop, degree of cultivar susceptibility and a great extent to the conduciveness of the environment in which it occurs (Akhtar et al., 2011). Bacterial blight is a vascular disease, therefore systemic in nature. Kresek and leaf blight are the two symptoms that occur in rice (Akhtar et al., 2008). The disease incidence and development is greatly influenced by topographic conditions, environmental conditions and cultural practices. Among these factors application of heavy fertilizer doses like nitrogen is mostly responsible for encouraging disease development (Cha et al., 1982; Reddy et al., 1979; Myintet al., 2007). Multiplication of bacteria in guttation also plays an important role in increasing the inoculum potentialand in turn contributes to disease development. The guttation exudates are a carrier of numerous organic and inorganic constituents (Feng and Kuo, 1975) and these may be playing a significant role in the multiplication and spread of $X$. oryzae $\mathrm{pv}$. ISSN : 0974-9411 (Print), 2231-5209 (Online) All Rights Reserved $\odot$ Applied and Natural Science Foundation www.jans.ansfoundation.org oryzae, and this chiefly enters through hydathodes (the point from where oozing of guttation fluid occurs) as suggested by electron microscopic studies (Horino, 1984; Mew et al., 1984). As this disease is known to be highly influenced by prevailing weather conditions, which affects both host and pathogen physiology. However the quantitative relationship between changes in host physiology due to prevailing weather and human interventions such as enhanced doses of nitrogenous fertilizers is poorly understood. This study helps in the understanding the effect of nutrition specially nitrogen on disease development.

\section{MATERIALS AND METHODS}

The experiments were conducted in Department of Plant Pathology, Punjab Agricultural University, Ludhiana, Punjab. Punjab pathotype, $\mathrm{PbXo-7}$ (Lore et al.,2011) of $X$. oryzae pv. oryzae was used to inoculate test rice cultivar Pusa 1121. Two plants were inoculated in the centre of each plot.The nitrogen doses were applied as $36 \mathrm{~kg} / \mathrm{acre}$ (U36), $54 \mathrm{~kg} /$ acre (U54) and 72 $\mathrm{kg} / \mathrm{acre}$ (U72) to rice crop. The nitrogen was applied in the form of urea. Nitrogen application was split into two, with first half applied after three weeks of transplanting and second applied after six weeks of transplanting. Three replications were kept for each treatment. The plots receiving no nitrogen served as control (U0).

Bacterial blight disease severity: Severity of disease in a plot was recorded as percentage of tissue area infected out of total leaf area. The data for disease severity 
was recorded periodically at 10, 20 and 30 days after inoculation at seedling, tillering and booting stage. Leaves from the marked plants were assessed to obtain average lesion area $(\%)$ for disease severity in each plot.

Collection of guttation fluid: Guttation fluid was gently collected with a micro-pipette (Ding et al.,2001) from the upper 10 leaves at an interval of 1 day, 14 days and 28 days after inoculation. The guttation fluid collected from rice leaf was then serially diluted up to $10^{-4}$ dilution. Plating was done for $10^{-3}$ and $10^{-4}$ dilutions. The viable colonies were manually counted and number of colony forming unit per $1 \mathrm{ml}$ of guttation fluid was calculated.

Preparation of sample and examination under scanning electron microscope: Leaves from inoculated rice plant were sampled after 96 hour of inoculation from rice plots supplied with $72 \mathrm{~kg}$ urea/acre, $36 \mathrm{~kg}$ urea/acre and no nitrogen. Leaves were detached at random, brought into the laboratory, and tissues around xylem were carefully cut out with a razor blade and fixed in $0.025 \mathrm{M}$ potassium phosphate buffer containing 3\% glutaraldehyde (pH 7.0) for $24 \mathrm{hr}$ at $4{ }^{\circ} \mathrm{C}$ and post fixed in $1 \%$ osmium tetroxide in the same buffer for $2 \mathrm{hr}$. The specimens were then washed three times with the phosphate buffer and subjected to serial dehydration with ethanol and Freon and critical-point drying with Freon 113. The specimens were coated with gold and examined with scanning electron microscopy (Mew et al., 1984).

The data on field for disease severity was statistically analyzed using SigmaStat version 11. The significance of difference was tested at five per cent level of probability.

\section{RESULTS AND DISCUSSION}

Effect of different nitrogen doses on population density of $X$. oryzae pv. oryzae in guttation fluid and colonization in rice leaves by scanning electron microscope: The population density of $X$. oryzae $\mathrm{pv}$.
Oryzae was highly influenced by the amount of nitrogen applied to the crop. As evident from Table 1, log cfu of bacteria in guttation fluid increased with increase in application of nitrogen level at both seedling and tillering stage of crop. At tillering stage, maximum $\log$ cfu (6.02) in guttation fluid was observed in plots receiving $72 \mathrm{~kg}$ urea/acre after 1 day of inoculation. The population density increased to 6.57 after 14 days and 6.59 after 28 days of inoculation. It was significantly (at $5 \%$ level of significance) higher than the plots receiving recommended dose of nitrogen fertilizer (Urea) where these values were observed to be 4.68, 5.93 and 6.01 respectively. Similar trend of increase in mean log cfu was seen when nitrogen dose was applied @ 54 kg urea/ acre and minimum log cfu was recorded in control (U0) plots. It was also seen that number of tillers per plant were significantly different at both seedling and tillering stage of crop among the four nitrogen treatments. When high dose of nitrogen (U72) was applied, number of tillers per plant was more (18 at tillering and 7 at seedling stage). It was followed by nitrogen dose of U54 and U36, where numbers of tillers were 14 and 13 respectively at tillering stage. Very less vegetative growth was seen when no nitrogen was applied to the field i.e 10 at tillering and 4 at seedling stage of the crop (Table 2). High nitrogen application resulted in more biomass in terms of number of leaves and tillers per plant. Although the amount of guttation fluid was significantly different on whole plant basis but not on individual leaves. This can be attributed to fact the nitrogen supply influenced tillering and number of leaf per plant, which together determine the size of the canopy produced and hence the amount of guttation fluid. The results showed the influence of amount of nitrogen applied on the population buildup of $X$. oryzae $\mathrm{pv}$. oryzae in rice guttation fluid. Nitrogen fertilizers influence the nutrient level of guttation fluid (Sakai, 1990) by increasing the total amino acids in the fluid. These free amino acids serve as enriched food source for

Table 1. Effect of different nitrogen doses on population density of X.oryzaepv. oryzaein guttation fluid in rice cultivar Pusa 1121 at seedling and tillering stage.

\begin{tabular}{|c|c|c|c|c|c|c|}
\hline \multirow{3}{*}{$\frac{\text { Nitrogen dose }}{\text { (Urea kg/acre) }}$} & \multicolumn{6}{|c|}{ Population density of $X$. oryzae pv. Oryzae (logcfu/ml guttation fluid) } \\
\hline & \multicolumn{3}{|c|}{ Seedling stage } & \multicolumn{3}{|c|}{ Tillering stage } \\
\hline & $\begin{array}{l}\text { 1day after } \\
\text { inoculation }\end{array}$ & $\begin{array}{c}14 \text { days after } \\
\text { inoculation }\end{array}$ & $\begin{array}{c}28 \text { days after } \\
\text { inoculation }\end{array}$ & $\begin{array}{l}\text { 1day after } \\
\text { inoculation }\end{array}$ & $\begin{array}{c}14 \text { days after } \\
\text { inoculation }\end{array}$ & $\begin{array}{c}28 \text { days after } \\
\text { inoculation }\end{array}$ \\
\hline $\mathrm{U} 36$ & $\begin{array}{l}7.5 \times 10^{4} \\
(4.29)^{b}\end{array}$ & $\begin{array}{l}3.4 \times 10^{6} \\
(6.47)^{\mathrm{d}}\end{array}$ & $\begin{array}{l}2.9 \times 10^{6} \\
(6.43)^{d}\end{array}$ & $\begin{array}{l}4.6 \times 10^{4} \\
(4.68)^{b}\end{array}$ & $\begin{array}{l}6.3 \times 10^{5} \\
(5.93)^{f j}\end{array}$ & $\begin{array}{l}8.9 \times 10^{5} \\
(6.01)^{\mathrm{j}}\end{array}$ \\
\hline U54 & $\begin{array}{l}5.2 \times 10^{5} \\
(5.61)^{c}\end{array}$ & $\begin{array}{l}4.4 \times 10^{6} \\
(6.56)^{d}\end{array}$ & $\begin{array}{l}3.7 \times 10^{6} \\
(6.49)^{d}\end{array}$ & $\begin{array}{l}5.5 \times 10^{4} \\
(5.33)^{c}\end{array}$ & $\begin{array}{l}9.8 \times 10^{5} \\
(6.29)^{\mathrm{gk}}\end{array}$ & $\begin{array}{l}1.3 \times 10^{6} \\
(6.30)^{\mathrm{k}}\end{array}$ \\
\hline $\mathrm{U} 72$ & $\begin{array}{l}8.6 \times 10^{5} \\
(5.87)^{\mathrm{c}}\end{array}$ & $\begin{array}{l}7.7 \times 10^{6} \\
(6.75)^{\mathrm{dg}}\end{array}$ & $\begin{array}{l}5.8 \times 10^{6} \\
(6.69)^{\mathrm{g}}\end{array}$ & $\begin{array}{l}6.3 \times 10^{5} \\
(6.02)^{\mathrm{d}}\end{array}$ & $\begin{array}{l}1.9 \times 10^{6} \\
(6.57)^{\mathrm{hl}}\end{array}$ & $\begin{array}{l}3.1 \times 10^{6} \\
(6.59)^{1}\end{array}$ \\
\hline No urea & $\begin{array}{l}1.0 \times 10^{2} \\
(2.06)^{\mathrm{a}}\end{array}$ & $\begin{array}{l}2.0 \times 10^{6} \\
(6.31)^{\mathrm{d}}\end{array}$ & $\begin{array}{l}2.0 \times 10^{6} \\
(6.24)^{d}\end{array}$ & $\begin{array}{l}2.2 \times 10^{4} \\
(4.72)^{\mathrm{a}}\end{array}$ & $\begin{array}{l}2.2 \times 10^{5} \\
(5.49)^{\mathrm{e}}\end{array}$ & $\begin{array}{l}6.1 \times 10^{5} \\
(5.79)^{\mathrm{i}}\end{array}$ \\
\hline $\mathrm{P}>\mathrm{F}(0.05)$ & N-dose & $<0.001$ & & N-dose & $<0.001$ & \\
\hline & DAI & $<0.001$ & & DAI & $<0.001$ & \\
\hline & N-dose x DAI & $<0.001$ & & N-dose x DAI & 0.013 & \\
\hline
\end{tabular}

Figures in parenthesis are the log transformed means. The figures followed by same letter do not differ significantly 
R. Kiran et al. / J. Appl. \& Nat. Sci. 8 (3): 1541 - 1545 (2016)

Table 2. Mean number of tillers and leaves per plant of rice cultivar Pusa 1121 at the time of inoculation.

\begin{tabular}{cccc}
\hline Nitrogen dose & Number of tillers per plant & $\begin{array}{c}\text { Mean number of leaves } \\
\text { per tiller* }\end{array}$ & $\begin{array}{c}\text { Amount of guttation fluid } \\
\text { collected per leaf }(\boldsymbol{\mu})\end{array}$ \\
\hline Seedling stage & $4^{\mathrm{a}}$ & 4 & 70 \\
U0 & $4^{\mathrm{a}}$ & 4 & 70 \\
U36 & $6^{\mathrm{b}}$ & 5 & 70 \\
U54 & $7^{\mathrm{b}}$ & 4 & 70 \\
U72 & $10^{\mathrm{c}}$ & 5 & 70 \\
Tillering stage & $13^{\mathrm{d}}$ & 4 & 70 \\
U0 & $14^{\mathrm{d}}$ & 4 & 70 \\
U36 & $18^{\mathrm{e}}$ & 4 & 70 \\
U54 & & 4 & \\
\hline
\end{tabular}

Amount of guttation fluid collected from atleast 10 leaves from each treatment; $*$ Mean number of leaves per tiller do not differ significantly; Figures followed by same letter do not differ significantly
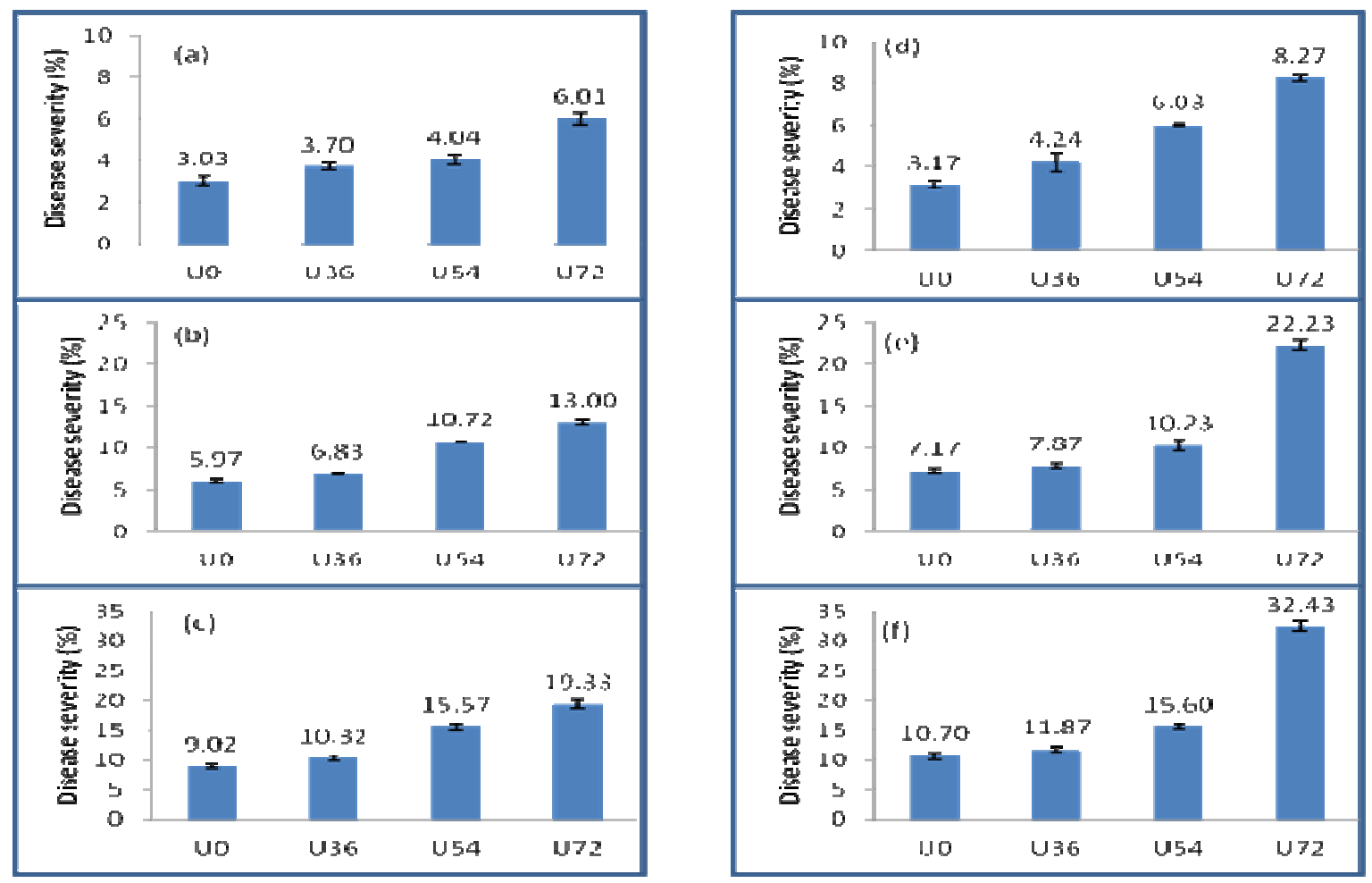

Fig. 1. Mean disease severity of bacterial blight under the influence of different $N$-doses. $(a),(b)$ and $(c)$ represents disease severity at 10, 20 and 30 days after inoculation in seedling stage whereas $(d),(e)$ and $(f)$ represents disease severity at 10, 20 and 30 days after inoculation at tillering stage.

plant pathogenic bacteria which feed on it and build up their populations in susceptible tissues as evident from this study. These results obtained above were also corroborated by electron microscopic studies. Multiplication of $X$. oryzaepv. oryzae and its colonization in the xylem vessels were investigated in rice leaves provided with different doses of nitrogen. About ten leaf specimens per treatment were examined under scanning electron microscope (SEM). The bacterial cells were all rod shaped and single celled (Fig.2). By scanning electron microscopic studies it accurately depicted the extent and intensity of bacterial colonization of host tissue (Mew et al., 1984). It revealed dense colonization of bacteria in leaf samples from plants supplemented with $72 \mathrm{~kg}$ urea/acre as compared to lower doses. These experiments suggest that application of high nitrogen favors pathogen multiplication and lesion enlargement and through increased vegetative growth of the plant.

Effect of nitrogen doses on disease severity of bacterial blight: Bacterial blight disease severity was recorded at different nitrogen doseson whole plot basis at seedling and tillering stage of the crop after 10, 20 and 30 days after inoculation. The disease severity in- 


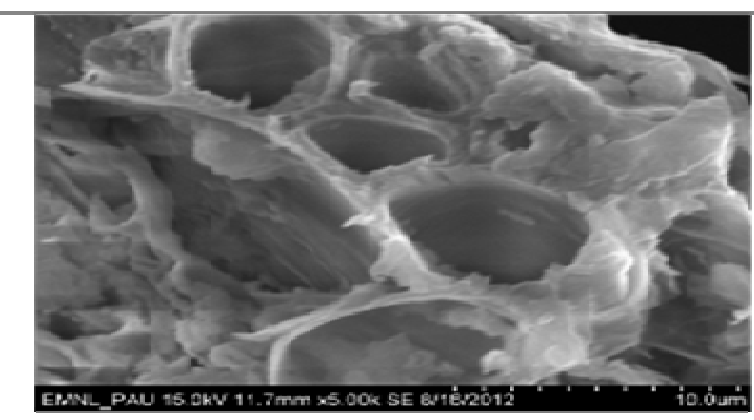

I

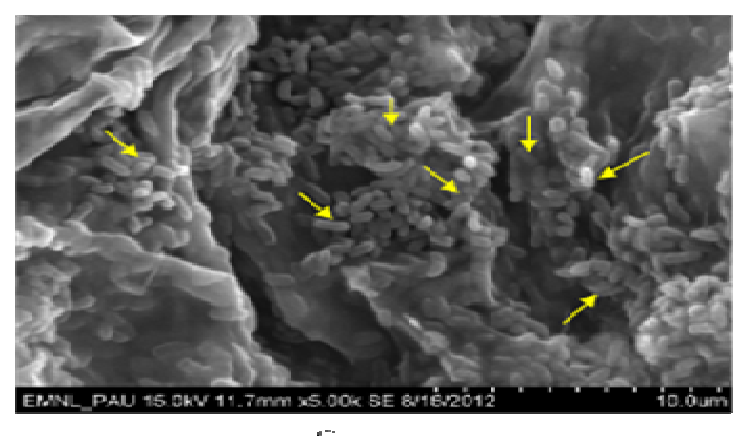

i.

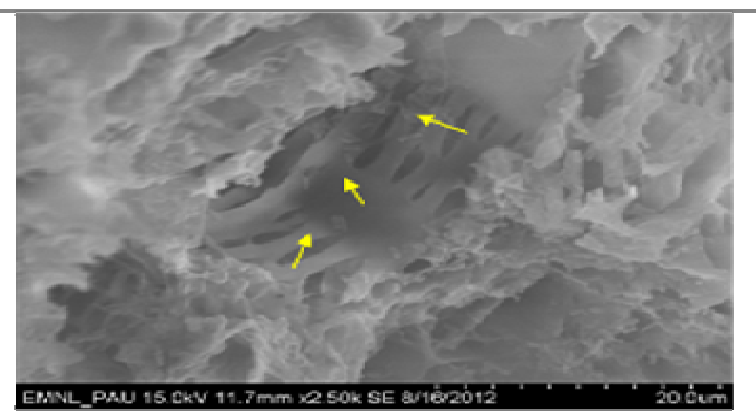

H.

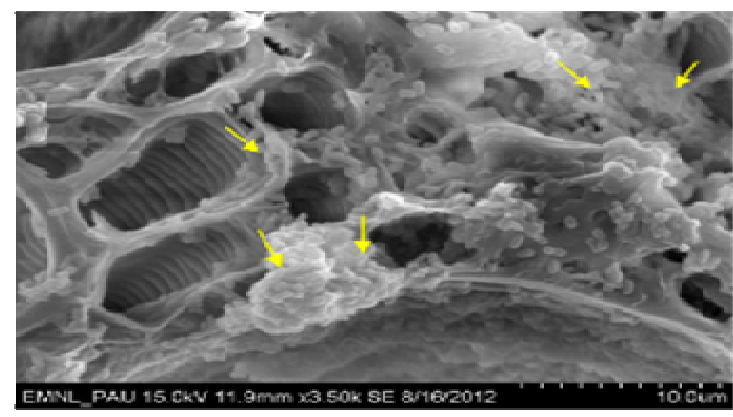

Ir

Fig. 2. Scanning electron micrographs of transverse section of rice leaves of cultivar Pusa 1121 sampled from A and B (No urea added) showing very less or no colonization; $C$ and $D(N$ added @ $72 \mathrm{Kg}$ urea/acre) showing high colonization by Xanthomonas oryzae pv. oryzae.

creased in linear trend and was maximum at 30 days after inoculation at both seedling and tillering stage of the crop, but the disease severity was more at tillering stage as compared to seedling stage of the crop. At tillering stage, maximum disease severity was seen in the treatment where urea was applied @ $72 \mathrm{~kg}$ urea/ acre $(32.4 \%)$ which was followed by U54 where disease severity was 15.6 per cent after 30 days of inoculation. Similar trend of increase in disease severity was observed after 10 and 20 days of inoculation. However, no disease was recorded when the crop was inoculated at booting stage of the crop (Fig. 1). Other workers have also reported direct correlation of excess or high nitrogen fertilizer application with increased disease severity (Ho and Lim, 1979; Mew et al., 1979; Reddy et al., 1979; Cha et al., 1982,; Myintet al., 2007) which corroborates the present study. Disease is also influenced by the time of nitrogen application and nitrogen availability also, excess nitrogen at late topdressing, increased the severity of bacterial blight of rice $(\mathrm{Ou}$, 1985).

\section{Conclusion}

In the present investigation, rice plots were supplied with different doses of nitrogen fertilizer (urea), the plots supplied with more than recommended levels of urea (72kg urea/acre and $54 \mathrm{~kg}$ urea/acre) showed significant increase in number of tillers per plant, significantly higher cfu of bacteria and inturn significant increase in bacterial blight disease of rice. So the prac- tice of increasing the doses of nitrogen above recommended dose should be avoided as it may increase the vegetative growth of rice plant but it also favors the bacterial blight of rice.

\section{ACKNOWLEDGEMENTS}

Raj Kiran (First author) is highly thankful to Indian Council of Agricultural Research, New Delhi to sanction Junior Research Fellowship to conduct these studies.

\section{REFERENCES}

Akhtar, M. A., Abbasi, F. M., Ahmad, H., Shahzad, M., Shah, M. A. and Shah A. H. (2011). Evaluation of rice germplasm against Xanthomonas oryzae causing bacterial leaf blight, Pak. J. Bot. 43(6): 3021-3023

Akhtar, M.A., Rafi A. and Hameed, A. (2008). Comparison of methods of inoculation of Xanthomonas oryzae pv. oryzae in rice cultivars. Pak. J. Bot. 40: 2171-2175.

Brar, J. S.(1992). Perpetuation of Xanthomonas oryzaepv. oryzae under North Indian conditions. Ph.D. Dissertation. Punjab Agricultural University, Ludhiana.

Cha, K. H., Lim, Y. S., Kim, H. J., Lee, D. K. and Kim, M. S. (1982). Effects of application of levels of fertilizer on the susceptibility to bacterial leaf blight, yield and quality of grains in nineteen rice cultivars in Jeonnam Region. Korean J. Plant Prot.21: 216-221.

Ding, X. S., Boydston, C. M. and Nelson, R. S. (2001). Presence of Brome mosaic virus in barley guttation fluid and its association with localized cell death response. Phytopathology. 91: 440-448.

Feng, T. Y. and Kuo, T. T. (1975). Chemotactic response of Xanthomonas oryzae toward water droplets collected 
from water pores on the leaf of rice plants. Bot Bull Acdemia Sinica. 16: 126-136.

Gnanamanickam, S. S., Priyadarshini, V. B., Narayanan, N. N., Vasudevan, P. and Kavitha, S. (1999). An overview of bacterial blight disease of rice and strategies for its management. Current Science. 77: 1435- 1443.

Ho, B. L. and Lim, W. C. (1979). Effects of nitrogen and planting density on bacterial blight Xanthomonas oryzae of rice. Malays. Agric. J.52: 171-176.

Horino, O. (1984). Ultrastructure of water pores in Leersia japonica Makino and Oryza sativa L.: Its correlation with the resistance to hydathodal invasion of Xanthomonascampestrispv. oryzae. Ann. Phytopathol. Soc. Jpn. 50:72-76.

Lore, J. S., Vikal, Y., Hunjan, M. S., Goel, R. K., Bharaj, T. S. and Raina, G. L. (2011). Genotypic and pathotypic diversity of Xanthomonasoryzaepv. oryzae, the cause of bacterial blight of rice in Punjab state of India. J. Phytopathol. 159: 479-487.

Mew, T. W., Mew, I. C. and Haung, J. S. (1984). Scanning of microscopy of virulent and avirulent strains of Xan- thomonascampestris pv. campestris on rice leaves. Phytopathology. 74: 635-641.

Mew, T. W., Vera Cruz, C. M. and Reyes, R. C. (1979). Effect of nitrogen on lesion development in rice resistant to bacterial blight. Int. Rice Res. Newsl. 4:12-13.

Myint, S. S., Nyunt, K. M., Ko, H. K. and Thein, M. M. (2007) Study on the effect of different urea fertilizer rates and plant populations on the severity of bacterial blight (BB) of Rice. J. Agr. Rural Dev. Trop. 108: 161-67.

Ou, S. H. (1985). Rice diseases. 2d ed, pp 360. Commonwealth Mycological Institute, Kew, Surrey, England.

Raina, G. L., Sidhu, G. S. and Saini, P. K. (1981) Rice bacterial blight status in Punjab, India. Int Rice Res Newsl.6: 13.

Reddy, A. P. K., Katyal, J. C., Rouse, D. I. and MacKenzie, D. R. (1979).Relationship between nitrogen fertilization bacterial leaf blight severity, and yield of rice. Phytopathology 69: 970-973.

Sakai, D. S. (1990). The effect of nitrate and ammonium fertilizer on the contents of Anthuriumguttation fluid. Proc $3^{\text {rd }}$ Anthurium Blight Conference. pp 18-21. University of Hawaii, Hilo. 